\title{
U.S. Geological Survey Programs in Maine
}

\section{U.S. Department of the Interior U.S. Geological Survey}

The U.S. Geological Survey (USGS) collects, compiles, and disseminates data on water, energy, biological resources, and mineral resources in the State of Maine. The USGS is known for its impartial datacollection and research mission to gather, interpret, and present data that enable resource planners and others to make informed decisions on the basis of objective information. As the Nation's leading earth science agency, the USGS works cooperatively with local, State, and Federal agencies to address issues related to earth resources. Today's earth science issues are more pressing than ever, which emphasizes the continuing need for informed resource development, describing and predicting the fate of toxic contaminants, and understanding the effects of human activities on natural resources.

\section{Identification of Potential Deposits of Metals}

The USGS has evaluated large areas in northern New England for deposits of copper, molybdenum, tin, tungsten, uranium, rare-earth elements, and gold. Identifying local sources of minerals that contain these metals will assist in the economic development of the region. Recent geochemical investigations identified belts of rocks that are favorable for deposits of copper and molybdenum in northern Maine and deposits of tin, tungsten, and uranium in southern Maine and Vermont. As a means of addressing environmental concerns about element mobility, USGS scientists are establishing geochemical data bases to document baseline element abundances for rock types that contain copper and molybdenum deposits, as well as measurements of the types of fluids involved during element migration.

\section{Mineral-Resource Information}

The USGS Mineral Resource Data System (MRDS) is a digital data base of more than 110,000 mineral sites in the United
States and worldwide. The MRDS provides up-to-date information on mineral occurrences and related data to support USGS research and mineral-resource assessments. It is the principal tool for providing mineral-related information to Federal and State agencies, industry, and the public. The records in this data base are compiled from the results of USGS studies and other published data. The MRDS contains information that mostly describes occurrences of sand and gravel and copper at more than 230 sites in Maine.

\section{Bald Eagle and Atlantic Salmon Studies}

The USGS Biological Resources Division (formerly the National Biological Service) conducts research and provides scientific data for land managers in the upper northeastern region of the United States. The Patuxent Environmental Science Center's Migratory Birds field station is investigating the implications for bald eagles of high mercury levels in fish from many lakes in this region; fish is their primary food source. Identifying habitat and food-chain impacts, such as localized high mercury concentrations, helps management agencies' efforts to maintain the eagle population. The eagle population suffered a drastic decline with the introduction of DDT and has slowly recovered in the last two decades.

The Fisheries field station of the Leetown Science Center is helping with efforts to restore the Atlantic salmon, which has been proposed for inclusion on the Endangered Species List as either threatened or endangered owing to significant declines in wild populations throughout its range in North Atlantic. Scientists at the station are studying habitat needs and migratory routes and examining populations of wild Atlantic salmon for the presence of unique genetic differences. Techniques developed at the field station to determine differences in DNA in

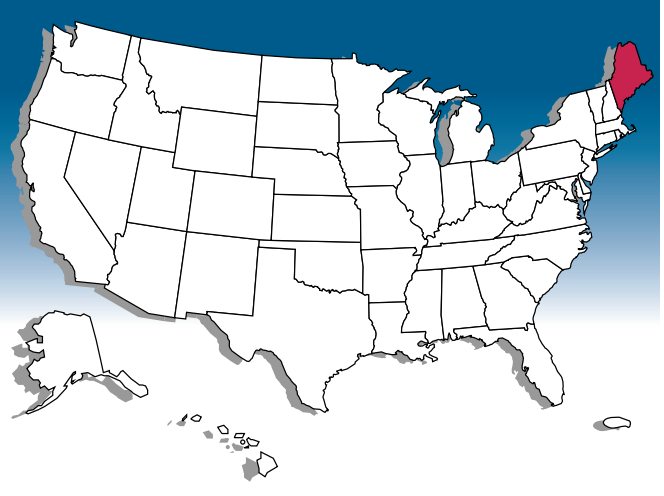

Index of Subjects

Identification of Potential Deposits of Metals

Mineral-Resource Information

Bald Eagle and Atlantic Salmon Studies

Aquifer Studies

National Water-Quality Assessment Program

Hydrologic Data Collection

Topographic Mapping

Earth Science Information Centers

Nonpoint-Source Contamination From Rural Highways

Studies at Superfund Sites

Contaminated Sediments in the Gulf of Maine

"Red Tide" Investigations in the Western

Gulf of Maine

Geologic Mapping

National Earthquake Information Center

Water-Use Information

salmon tissues from various populations enables managers to identify actual population sizes and provides a sound scientific basis for regulatory agencies to determine whether the species should be listed. The two cooperative research units at the University of Maine conduct studies on fisheries management and water-quality issues and wildlife management issues.

\section{Aquifer Studies}

Sand and gravel aquifers are the primary sources of water capable of meeting the water-supply requirements of municipalities and industries in Maine. They also are the source of water for many domestic wells. Information from detailed aquifer mapping and test drilling is required to evaluate, manage, and protect these ground-water resources effectively.

In 1981, the USGS, in cooperation with the Maine Department of Conservation of the Maine Geological Survey (MGS), and the Maine Department of Environmental Protection, began a long-term program to evaluate and map Maine's sand and gravel aquifers. Objectives of the program include identifying the principal aquifers and accurately mapping their boundaries; determining aquifer yield, stratigraphy, depth to 
water table and bedrock; and characterizing regional ground-water chemistry. Reports are compiled and released after each summer field season. The field work for this study is complete; northwestern Maine was not included in this study.

\section{National Water-Quality Assessment Program}

In 1991, the USGS began a full-scale National Water-Quality Assessment (NAWQA) Program. The objectives of this Program are to describe the quality of large, representative parts of the surfaceand ground-water resources of the United States and to identify the primary natural and manmade factors that affect the quality of these resources. Products of the NAWQA Program include information that is useful to water-resource policymakers and managers at Federal, State, and local levels. Data for evaluation of surface- and ground-water quality, riverbed sediments, and aquatic organisms are being collected across the United States in numerous NAWQA study units.

The New England Coastal Basins NAWQA study unit contains a 22,900square-mile drainage area that encompasses central and western Maine, central and eastern New Hampshire, eastern Massachusetts, and most of Rhode Island (fig. 1). Important drainage basins include the Kennebec, the Androscoggin, and the Saco River Basins in Maine, the Merrimack and the Saco River Basins in New Hampshire, the Merrimack, the Charles, the Taunton, and the Blackstone River Basins in Massachusetts, and the Blackstone River Basin in Rhode Island.

This study, which begins in 1997 , assesses some of the important waterquality issues in the region. These issues include the following:

- The presence and distribution of toxic substances in rivers and ground water;

- The effects of land use, reservoirs, and releases of treated wastewater on surface-water quality;

- The contribution of upland sources to contamination in coastal waters;

- The presence of high concentrations of naturally occurring trace elements and radon gas in some aquifers;

- The occurrence of synthetic, organicchemical contaminants in surface and ground water; and

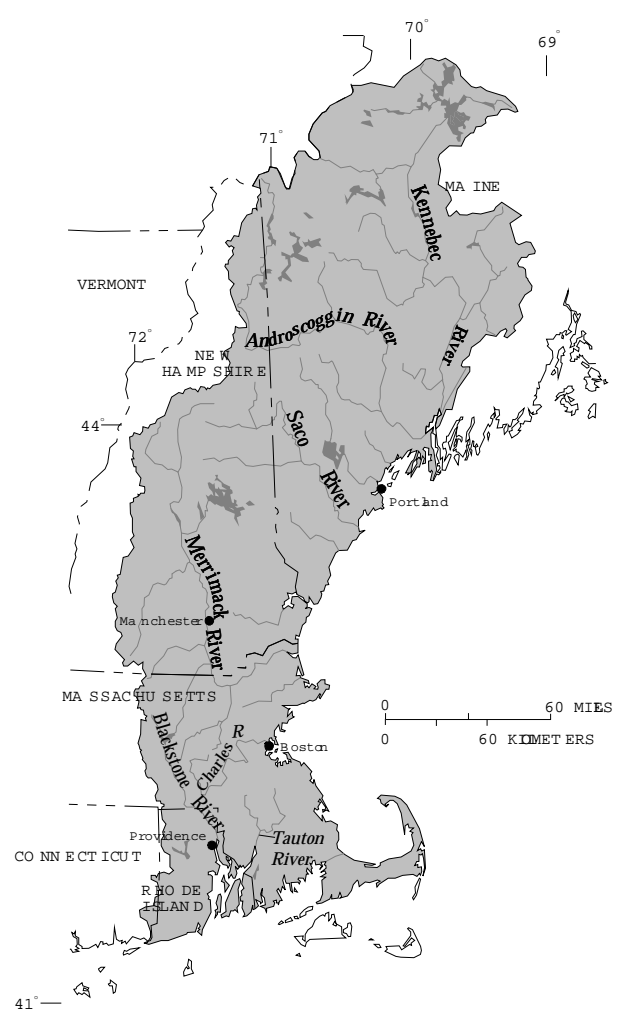

Figure 1. National Water-Quality Assessment Program study area.

- The relation of fish and aquatic insect communities to upstream land-use practices.

A local committee of representatives from Federal, State, and local agencies; universities; and the private sector works closely with the USGS during each NAWQA study. The purposes of these committees are to exchange information on regional and local water-quality issues and to assist in designing and planning project products to meet the needs of water-resource managers and the public in the study units.

\section{Hydrologic Data Collection}

The USGS statewide program of waterdata collection in Maine monitors the amount and quality of water in the State's rivers, streams, lakes, reservoirs, and aquifers (fig. 2). These data are used by water-resources managers and planners for flood forecasting; water-resources planning; design and operation of projects for water supply, hydroelectric power, flood and pollution control, and other purposes; designing bridges and culverts; flood-plain management; and hydrologic research. Long-term records are needed to evaluate the responses of hydrologic systems to natural climatic variations and humaninduced stresses so that potential problems can be defined early and appropriate planning and management actions can be taken by local and State officials.

Since 1901, the USGS has maintained the only network of streamflow-gaging stations in Maine, which provides streamflow information statewide. In addition, most of these streamflow-gaging stations have satellite data-relay capability, which can provide streamflow data to users on a near-realtime schedule. The USGS also provides detailed statistical analyses of streamflow information for all locations where sufficient flow data have been collected. These data are available for use by individuals or organizations concerned with water-resources issues or problems in Maine. As of 1995, 43 streamflow stations were in the network, and data and information were available for an additional 63 stations in the historical data base.

For more than 50 years, the USGS has maintained the only statewide network of observation wells to provide groundwater data for Maine. As of 1995, 31 observation wells were in the network, and data and information were available for an additional 36 wells in the historical data base.

Since 1952, the USGS has developed the only continuously operating statewide network of water-quality data-collection sites for Maine. The network includes sites where dissolved oxygen, specific

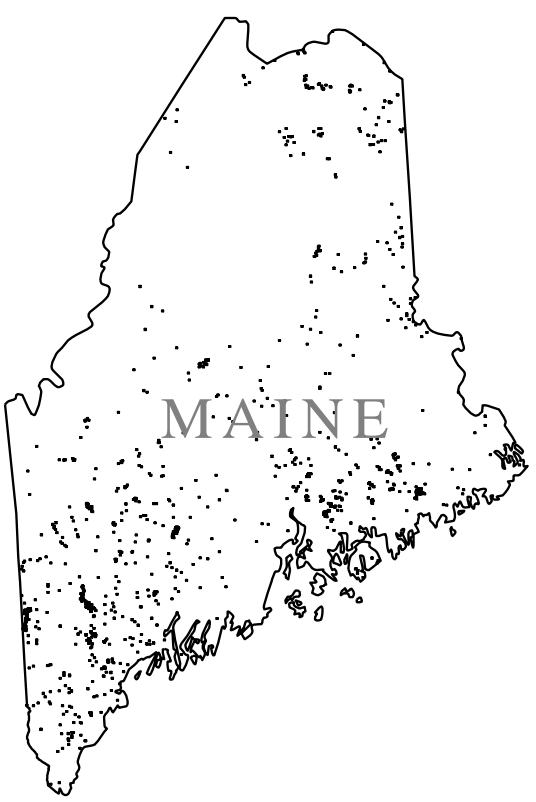

Figure 2. Historical hydrologic datacollection sites. 
conductance, $\mathrm{pH}$, and water temperature are measured hourly, and the data are available in realtime; sites where water samples are periodically collected and analyzed for chemical and physical properties; and one site located near the White Mountain National Forest, where a Hydrologic Benchmark Station has been in operation since 1964 to monitor long-term trends in ambient water-quality conditions in a pristine watershed. As of 1995, 16 water-quality stations were in the network, and data and information were available for an additional 64 sites in the historical data base.

The hydrologic information collected for these three networks is published annually in the report Water Resources DataMaine. Statewide streamflow and groundwater conditions are reported monthly in Current Water Resources Conditions in Maine.

\section{Topographic Mapping}

Through its National Mapping Program, the USGS strives to ensure the availability of map data in graphic and digital forms to the public through timely and effective data-collection and revision procedures. The use of maps and digital cartographic data is widespread. Among the most popular and versatile products of the USGS are its 1:24,000-scale topographic maps (1 inch on the map represents 2,000 feet on the ground). These maps depict natural and cultural features of the landscape, such as lakes and streams, highways and railroads, boundaries, and geographic names. Maine is covered by 803 maps at this scale, of which 20 percent have boundary, transportation, and hydrography data digitized and about 30 percent have digital elevation model data available. The National Mapping Program fosters partnerships with State and Federal agencies to improve the effectiveness of its data-collection activities, to maximize resource sharing, and to enhance the availability of timely and accurate data to the general public.

\section{Earth Science Information Centers}

The Earth Science Information Centers (ESIC) provide information about USGS programs, products, and technological developments to the public. The ESIC in Augusta was established under a cooperative agreement between the USGS and the MGS. As part of the national ESIC network, this office provides information on such earth science topics as cartography, geography, digital data, remote sensing, geology, geophysics, geochemistry, hydrology, geohydrology, aerial photography and land use. It is supported by the USGS with reference materials, technical assistance, training and outreach activities, and access to USGS data bases.

\section{Nonpoint-Source Contamination From Rural Highways}

In Maine, rural highways are a potential nonpoint source of phosphorus and trace metals to surface water. Previous studies have not examined water-quality characteristics of runoff from rural highway systems in the Northeastern United States. Determining highway runoff values for phosphorus, sediment, and selected trace metals can define the magnitude of the problem and provide information for responsible agencies to develop mitigation measures.

In 1992, the USGS, in cooperation with the Maine Departments of Transportation and Environmental Protection, began a study of three rural highways in central Maine. The objectives of the study include determining concentrations of total phosphorus, dissolved phosphorus, and suspended solids in runoff from the three study sites, as well as concentrations of dissolved and total copper, chromium, lead, nickel, and zinc.

\section{Studies at Superfund Sites}

Under the Comprehensive Environmental Response, Compensation, and Liability Act of 1980 (amended by the Superfund Amendments and Reauthorization Act of 1986), a list has been compiled of sites throughout the United States that are contaminated with hazardous materials; these are known as Superfund sites. The USGS, in cooperation with the U.S. Environmental Protection Agency (USEPA), is studying the regional and local geohydrology at selected Superfund sites.

In 1995, technical assistance to the USEPA was provided by the USGS at the Saco Municipal Landfill and the Saco Tannery Superfund sites. USGS assistance also had been provided at the U.S. Air Force-Loring Airbase to assess waterquality conditions on and around the base during its deactivation. The USGS assistance at these sites included assessments of problems related to ground-water hydraulics, surface-water runoff, waterquality conditions, and analyses of geohydrologic systems.

\section{Contaminated Sediments in the Gulf of Maine}

Many types of contaminants are ultimately deposited in sediments in the Gulf of Maine, where they can adversely affect the commercial and recreational uses of marine resources. The USGS is assembling existing data on contaminants in sediments as part of a study to assess contaminant levels and transport pathways in the Gulf. The data base is used to create maps of contaminant distribution; to provide information to local, State, and Federal regulatory agencies; and to address specific questions about the transport and long-term fate of contaminants in the waters of Maine, New Hampshire, and Massachusetts. The study is developing a method for establishing and using a national contaminated sediments data base. Preliminary maps indicate that "halos" of elevated contaminant concentrations commonly exist in marine-surface sediments for tens of miles offshore from urban or industrial centers. The study is conducted cooperatively with investigators from regional academic institutions and is partially supported by the National Oceanic and Atmospheric Administration's Regional Marine Research Program.

\section{"Red Tide" Investigations in the Western Gulf of Maine}

Blooms of Alexandrium tamarense, which is a toxic red microorganism, have become a serious economic and public health problem that affect nearshore and offshore shellfish resources and fish and marine mammal populations in the Gulf of Maine. This so-called "red tide" phenomenon, which has expanded in recent years to include more areas and more fisheries resources, can be managed most effectively if the hydrodynamic, nutritional, and biological mechanisms that underlie the population development of the microorganism are understood. USGS scientists are using 
a combination of numerical modeling, hydrographic and biological measurements, moored and drifting current measurements, and satellite imagery to quantify the structure, variability, and mechanics of the coastal current in the western Gulf of Maine.

The study area extends from Penobscot Bay in the north to Massachusetts Bay in the south. USGS scientists are testing the hypothesis that a source population of algae in southern Maine is carried southwestward along the coast in a buoyant coastal plume. The distribution of the plume is determined by wind stress, runoff, and general water circulation in the Gulf of Maine. Some of these blooms enter Massachusetts Bay, and others continue along the coast across Stellwagen Bank and onto Georges Bank. This study provides a quantitative understanding of the physics, biology, and chemistry of the regional red tide phenomenon. From this research, a numerical model is under development that can be used by managers concerned not only with toxic algae, but also with long-distance transport of dissolved and particulate contaminants. This work is conducted cooperatively with the Woods Hole Oceanographic Institution, Oregon State University, and the University of New Hampshire and is partially supported by the Gulf of Maine Regional Marine Research Program.

\section{Geologic Mapping}

Surficial geologic mapping of the distribution of sand, gravel, silt, clay, and till is conducted by the MGS and the USGS.

Geologic mapping is conducted mainly in southwestern Maine where most of the population growth has occurred and where the need for geologic information regarding water supplies, waste disposal, and construction requirements is greatest. In addition, bedrock geologic mapping has been conducted in the southern part of the State by the MGS in cooperation with the State Map Program and the USGS. Bedrock geologic mapping has been used for land-use planning, particularly near the coast. Geologic maps also are used by earth science teachers in the State and by National and State Park naturalists to increase public appreciation of unique geologic features in the parks. A new gravity map of the State and other geophysical data sets are important resources.

\section{National Earthquake Information Center}

The National Earthquake Information Center (NEIC) in Golden, Colorado, collects, processes, and distributes information from more than 20,000 seismic events each year. This information is distributed in the form of alerts, bulletins, and routine catalogs to emergency management officials at the Federal and State level, operators of critical facilities, news media, the general public, and the earthquake research community. These catalogs of recent and historical earthquake information are used in assessments of earthquake hazards. To fulfill its mission better, the NEIC has developed and is deploying the U.S. National Seismograph Network (USNSN), which, when completed, will consist of about 60 seismograph stations nationwide. The USNSN monitors nationwide seismicity, provides early notification of seismic events to national level emergency-services personnel, maintains an archive of high-quality digital data on national seismicity, and provides public information on earthquakes.

In Maine, the seismic network is coordinated by the MGS. The MGS is a member of the Northeastern U.S. Seismic Network, which is a consortium of universities, State and Federal agencies, and private companies that monitor and record seismic activity in the Northeast. Seismic data in Maine are recorded on instruments run by the Massachusetts Institute of Technology and Boston College. These data are then fed to the NEIC, where the MGS obtains daily seismic reports automatically over the Internet to respond to inquiries regarding seismic activity in Maine.

\section{Water-Use Information}

In southwestern and coastal Maine, water resources are increasingly stressed by new demands. Competition for water in the future will require that information on water availability and use be accurate so that the State can plan and manage water rights and water allocation programs. The MGS and the Maine Department of Human Services cooperate with the USGS in collecting, archiving, analyzing, and reporting on water-use trends in Maine. The data are entered into the New England Water-Use Data System, which is accessible to the State and other users by computer; reports are published at set intervals.
USGS State representative 26 Ganneston Drive Augusta, ME 04330

(207) 622- 8201

Fax: (207) 622-8204

Email:dc_me@usgs.gov

Additional earth science information can be found by accessing the USGS Home Page on the World Wide Web at http://www.usgs.gov/

\section{For more information on all USGS reports and products (including maps, images, and computerized data), call 1-800-USA-MAPS}

The USGS provides maps, reports, and information to help others meet their needs to manage, develop, and protect America's water, energy, mineral, biological, and land resources. We help find the natural resources needed to build tomorrow, and supply the scientific understanding needed to help minimize or mitigate the effects of natural hazards and environmental damage caused by natural and human activities. The results of our efforts touch the daily life of almost every American. 